\title{
Chinese Women's Family Status: Analysis of Chinese Decennial Surveys, 1990-2010
}

\section{By Jiehua Lu ANd XiaOfei Wang}

\begin{abstract}
Chinese Women's Family Status: Analysis of Chinese Decennial Surveys, 1990-2010

The experiences and status of Chinese women have significantly changed over the last two to three decades, along with China's modernization. In this article we investigate the domestic division of labor between the two sexes at the present-day in the context of gender equality. Based on data from three Surveys on Chinese Women's Social Status taken in 1990, 2000 and 2010, the article focuses on important dimensions of women's family status, such as general changes in domestic decision-making and the time women spend in domestic labor, including rural-urban differences. The article points to "equal rights for both husband and wife" (Fu Qi Ping Quan, 夫妻平权) as being the major pattern in domestic decision-making, yet men have still more rights than women. Also, women are still the main force in domestic labor, although the difference between the times spent in domestic labor by women and men respectively has gradually narrowed. There also seems to be a greater correlation between education and women's status in rural areas than in urban areas.
\end{abstract}

\section{KEYWORDS}

Family, gender equality, domestic work, women's status

Dr Jiehua Lu, Professor, Department of Sociology, Peking University. His research interests mainly deal with ageing, demography, social policy, etc.

Xiaofei Wang is a PhD fellow at the Department of Sociology, Peking University. Her research interests include population health, quantitative methodology, education, etc. 




in the family depend on women's status in the given structure of resources and of society. As Chinese society progressively modernizes, the empowerment of Chinese women in education, careers and marriage has significantly changed their status and experience: Since 1950, the marriage law of the People's Republic of China has stated that both men and women are free to marry, that marriages should be monogamous, that men and women have equal rights, but also that women should be protected. Mao's renowned statement, "Women hold up half the sky" (Fu Nv Neng Ding Ban Bian Tian, 妇女能顶半边天), was not only an affirmation of women's abilities, it also further increased women's family and economic status. The law of the People's Republic of China on the Protection of the Rights and Interests of Women, passed in 1992, specified that men and women have equal social status and political rights. According to the China Statistical Yearbook for 2012, released by the National Bureau of Statistics of China, $51.2 \%$ of Chinese degree-level students were female. Also, according to the sixth census in 2010, $51.1 \%$ of professional technicians were female. These data indicate that women's educational status has caught up with and is surpassing that of men (Yu 2014). To a certain extent, married women's participation in domestic labor and their domestic decision-making power are important indicators that reflect their family status. In addition, these are key factors in judging women's social status and gendered power relations ( $\mathrm{Li}$ 2013). In this article we understand factors affecting women's family status and functions through the analysis of their domestic decision-making power and domestic labor situation. We will focus on urban-rural differences because of the huge differences in China between urban and rural women in terms of educational level, the distribution of resources and patterns of family decisionmaking. We find that women's domestic decision-making power and domestic labor situations have a direct influence on their levels of satisfaction with their family status.

\section{LITERATURE REVIEW OF THE STATUS OF WOMEN WITHIN THE FAMILY}

Women's social status reflects the level of civilization in a society, while women's family status, in its turn, is an essential factor in measuring their social status (Wang 2013). Social and economic development allows women to leave their homes so that they are no longer fully reliant on their families. Not only have they been able to realize economic independence in this period, they have also reshaped gender consciousness, meaning that they are gradually ridding themselves of the traditional gender division of labor and are in the process of achieving equal social status for themselves in relation to men. However, women's social status still fluctuates due to economic development and industrialization (Liu and Zhao 2011), and they are still faced with the dilemma of balancing the needs of their families with the development of their own careers ( $\mathrm{Li}$ 2011). Research has shown that, compared to men, women still do most of the domestic work (Bianchi et al. 2006, Yang 2014, Yu 2014), and have not changed their role of "being inside the house (Zhu Nei, 主内 )", which revolves around keeping house. The inequality between the two sexes found in domestic labor has created women's unfavorable position in the labor market (Becker 1985; Noonan 2001), which in turn has affected their levels of satisfaction with their incomes, standards of living and family status.

Existing studies (Guo et al. 2007, Gong and Zhong 2009, Chen 2011, Cao and 
Yang 2014, Wu 2014) usually measure women's marital familial status with respect to the following aspects: women's marital autonomy, reproductive rights, decisionmaking power over family matters, right to take possession of family resources, economic status within the family, etc. Generally speaking, women's family status refers to the extent to which women are able to control their families when compared to men. A woman's level of control and authority depends on the resources that both sexes are willing to contribute to marriage, the so-called 'relative-resource perspective' first suggested by Robert Blood and Donald Wolfe in their book Husbands and Wives: The Dynamics of Married Living (1960). This pioneering study put forward a resource theory to explain marital power. It suggested that an individual's authority and power in a marriage come from a comparison of the resources the couple possesses individually (Liu and $\mathrm{Li}$ 2013). The person who possesses the most resources is in the best position to dominate and change the other spouse's behavior. And when the resources one possesses are particularly rare or important to the family, one has greater family power (Song 2012). This perspective emphasizes the differences in structural resources between the couple (Yang 2014), and the domestic division of labor may be a good proxy to show such differences. The impact of relative resource levels on the domestic division of labor is mainly reflected in the allocation of domestic labor time (Brines 1994). Women with higher education levels and incomes are able to provide a higher economic contribution to the family. The theory claims that this would likewise result in a reduction in their domestic labor time. On the other hand, in families where the husbands contribute more than the wives, it is argued that women have to achieve a "contribution balance" between the two by participating more in housework. According to the relative-resource perspective, one's family power is related to one's contribution to the family, yet one's contribution is not the only determinant of this. The power and status of each family member also falls under the impact of norms such as different cultural traditions and social customs (Wang 2005).

Unlike the relative-resource perspective, functionalist approaches contend that the division of labor and the distribution of power and status are the result of the functions of the family. In order to maintain the normal operation of a family and to achieve the greatest benefit to it, men and women have to co-ordinate their labor. To ensure the family's standard of living, men usually take up the external, productive and occupational function, while women mainly remain in the house doing housework, mothering, and maintaining family relationships. In this case, women are more like the emotional leader who exerts "emotional functions" and satisfies the needs of family members for emotional comfort (Becker 1981, Yang 2014).

Resource theory and functional theory provide us with two different perspectives with which to explain the distribution of power within the family and the relative statuses of husbands and wives. Along with the numerous factors that affect married women's family status, domestic labor time and domestic decision-making power are the most important in determining women's social status and gender power ( $\mathrm{Li}$ 2013). The time-availability perspective offers us a new angle from which to look at the domestic division of labor. It suggests that domestic labor is based on family members' availability, and the time that men and women spend on domestic labor is correlated with the time they spend in the labor market. According to existing research on women's domestic decisionmaking power, "equality between men and women" is the major pattern in deciding family matters, and it is becoming more common (Wang 2009, Wang 2013). How- 
Table 1. Dependent variables studied in this article

\section{Name of dependent variable}

1. Whether or not women have domestic decisionmaking power

\section{Women's domestic labor time}

\section{Women's satisfaction level of their family status}

Meaning of the variable and the original statement in the questionnaire

Who has more authority in family? (1. husband 2. wife 3 . similar)

Interviewees' time spent on housework before the day of the interview (including cooking, cleaning, taking care of family members, daily purchases etc.)

All in all, are you satisfied with your family status? (1. Very satisfied 2. Quite satisfied

3. Fair 4. Quite dissatisfied 5. Very dissatisfied)
Variable assignment

$$
\begin{aligned}
& 0=\text { None }(\text { category } 1) \\
& 1=\text { yes }(\text { categories } 2 \& \\
& 3 \text { collapsed) }
\end{aligned}
$$

Continuous variable minute as unit
$0=$ Dissatisfied (category 3, 4 and 5 collapsed) $\mathrm{l}=$ Satisfied (category $\mathrm{l}$ and

2 collapsed) ever, the rights of men are still greater than those of the women in the family. Moreover, according to research on the time married women spend in domestic labor (Xu and Liu 2003, Li 2013, Yang 2014, Yu 2014), the time women devote to domestic work is affected by their educational levels, working hours and income: the higher these levels, the lower the time spent in domestic labor (henceforward 'domestic labor time').

This article uses the results of survey data from 1990, 2000 and 2010 to investigate the dynamic changes and trends in domestic decision-making power and domestic labor time in the past twenty years. $^{1}$ Next we will analyze in greater depth the factors that affect women's domestic decision-making power and domestic labor time based on data from 2010. This will include an analysis of ruralurban differences in those factors that affect women's self-evaluated levels of satisfaction with their family status.

Table 1 lists the dependent variables that will be investigated in the following, the descriptions of these variables in the original questionnaire and their assignment after the readjustment of their categories.

\section{DATA AND METHODOLOGY}

Since our research focuses on married women's domestic decision-making power, domestic labor time and their levels of satisfaction with their family status, we only investigate women whose civil status is "married", based on the data of Survey on Women's Status in 1990, 2000 and 2010.2

'Married women's satisfaction levels with their family status' corresponds to women's subjective assessment and this is often dependent on their considerations of factors such as contribution to the family, the family resources they control, their family authority level, etc. Women's domestic decision-making power also varies according to their education levels, personal abilities and economic status relative to their husbands. And such gendered power rela- 
Table 2. Descriptive statistics of variables

\section{Urban}

\section{Dependent variables}

Time (min.) spent on domestic labor by women

Women have decision-making power

Women are satisfied with family status

\section{Independent variables}

Who has a better pre-marriage family

financial situation?

Men

17.9

Mean Std. err.

190.20

73.4

88.3
Rural

Mean Std. err.

$171.31 \quad 1.608$

56.8

84.5

Women

21.8

16.3

Similar

60.3

19.1

Who contributes more economically to the family?

Husband

58.1

71.9

Wife

10.5

4.7

Similar

31.4

23.3

Who takes up domestic labor?

Husband

7.4

8.4

Wife

Similar

Women's education level

Illiterate or semi-illiterate

Primary school

Junior high

High school and above

tions can be reflected in the allocation of domestic labor time. Naturally both domestic decision-making power and domestic labor time may influence a woman's subjective assessment of her family status.

Table 2 gives basic descriptive information of the key dependent and independent variables in our analysis by rural-urban area. $^{3}$

\section{ANALYTICAL RESULTS}

1. Dynamic change to women's domestic decision-making power and factors affecting this in the past two decades

In married families, domestic decisionmaking power is a crucial dimension in determining gender-related power within the family structure. According to relativeresource theory, the greater one's control over a family resource, the greater one's 
Table 3. Trends in the percentage of husband's and wife's domestic decision-making power from 1990 to 2010

\begin{tabular}{lllll}
1990 & \multicolumn{2}{c}{2000} & \multicolumn{2}{c}{2010} \\
$\begin{array}{l}\text { Hus- Wife Joint } \\
\text { band }\end{array}$ & $\begin{array}{l}\text { Hus- Wife Joint } \\
\text { band }\end{array}$ & $\begin{array}{l}\text { Hus- Wife } \\
\text { band }\end{array}$ & Joint
\end{tabular}

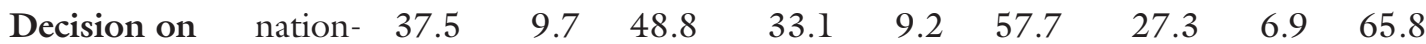
engaging in wide

type of $\begin{array}{lllllllllll}\text { agricultural } & \text { urban } & 22.0 & 9.8 & 65.8 & 24.1 & 9.7 & 66.2 & 22.1 & 7.8 & 70.1\end{array}$

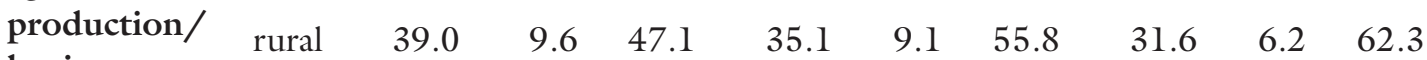
business

Housing choice/ building a house $\begin{array}{llll}\text { nation } & 31.6 & 3.2 & 60.7\end{array}$ wide

$\begin{array}{llll}\text { urban } \quad 27.9 & 6.6 & 62.7\end{array}$

$\begin{array}{llll}\text { rural } & 32.2 & 2.6 & 60.3\end{array}$ $\begin{array}{lll}21.3 & 6.0 & 72.8\end{array}$

32.0

$3.2 \quad 64.8$
$21.4 \quad 41.8 \quad 36.7$

$\begin{array}{lll}14.2 & 49.0 \quad 36.8\end{array}$

$\begin{array}{lll}23.8 & 39.5 & 36.7\end{array}$ $\begin{array}{lll}11.2 & 53.9 & 34.9\end{array}$

$19.2 \quad 45.3 \quad 35.5$


high-end wide

products /

large

urban

$12.1 \quad 8.0 \quad 77.9$

24.2

12.6

63.3

21.9

$11.6 \quad 66.5$

production tools

rural

26.4

$5.3 \quad 64.4$

40.9

$6.7 \quad 52.4$

35.9

Investment/

nation- 38.3

$4.0 \quad 53.8$

39.6

$5.0 \quad 55.5$

25.3

$5.6 \quad 58.5$ loan

wide

urban 18.6

$6.7 \quad 72.7$

26.6

$6.8 \quad 66.6$

20.4

$6.7 \quad 72.9$

rura

$3.7 \quad 52.0$

42.7

$\begin{array}{ll}4.5 & 52.7\end{array}$

$29.9 \quad 3.2 \quad 66.8$

$\begin{array}{lllllllllll}\text { Education/ nation- } & 24.1 & 6.8 & 65.8 & 21.2 & 7.2 & 71.7 & 16.1 & 11.4 & 72.5\end{array}$ career choice of children

\section{wide}

urban $\quad 15.0 \quad 7.0 \quad 77.6$

$\begin{array}{lll}15.4 & 10.1 \quad 74.5\end{array}$

$12.3 \quad 13.6 \quad 74.1$

rura

$6.7 \quad 63$.

23.0

$6.2 \quad 70.8$

20.

$9.2 \quad 70.7$ 
individual influence and control over gender relations. Women's power in the family is, on the one hand, affected by factors such as education levels and incomes. On the other hand, a woman's power in the family also changes with the transformation of the socio-cultural environment she is a part of (Wang 2009). Therefore, it is necessary to analyze the dynamic change in women's domestic decision-making power from a temporal perspective. In all three phases of the survey on Chinese women's social status, we find measurements of decision-making power regarding domestic matters exemplified through six dimensions: daily family expenses, purchases of goods for the whole family, investment, children's education, etc. Table 3 summarizes the percentage of domestic matters that are decided by husbands only, wives only and both; it also shows trends and rural-urban differences.

\section{a. General characteristics of domestic decision- making power in the past twenty years}

Generally speaking, "taking a joint decision" seems to have been the dominant pattern in how decisions are made between husband and wife in both urban and rural families in the past two decades. Apart from decisions on "domestic daily expenses" and "purchases of high-end products/large production tools", joint decisions in all the other four aspects have increased. This may indicate that "equality for husbands and wives" is the major characteristic of family power relations. Seen from the data collected in the three surveys, the percentage of husbands making individual decisions is always higher than that of wives. This shows that, regarding family decisions on important economic matters, such as investments and purchases of property, the percentage of husbands' making individual decisions is far greater than that of wives. This indicates that husbands are in charge of the finances and that they control the property in the family.

\section{b. Rural-urban differences in domestic decision-making power in the past twenty years}

There is a significant difference between rural and urban women in domestic decisionmaking power and family status. This is due firstly to the differences in educational level, income, resource allocation and cultural traditions. Secondly, traditional production methods still exist in some rural areas, and some rural women are still constrained by the conventional family pattern of "men on the outside, women on the inside" (Nan Zhu Wai, Nv Zhu Nei. 男主外，女主内。). We learn from Table 3 that, from 1990 to 2010, when it comes to major economic decisions such as family housing and investment, the percentage of husbands making the decision alone is always higher than that of wives; moreover, the percentage of rural husbands making decisions alone is always higher than that of urban husbands. This reflects the fact that the authority of rural husbands is greater than that of urban husbands in the family. Although "joint decision-making" is still the basic pattern of the distribution of family power in both rural and urban areas, the percentage of urban married couples making decisions together is always higher than that of rural married couples. This reflects the fact that urban married couples enjoy more equal rights than rural married couples.

In fact, women's status has improved considerably in the past two decades due to the rapid development and progress of Chinese society. Awareness of equality between men and women has also increased. As a result, the percentage of husbands making decisions alone in domestic matters is dropping more quickly than in the case of urban husbands; the gap in the extent of "equality between husband and wife" between rural and urban areas is also shrinking substantially. Although equality between husband and wife is more common in urban areas, the percentage of rural 
Table 4. Model 1. Logistic regression model of whether married women have domestic decisionmaking power in the family. Coefficients are in odds ratio.

Wife's education level

$\begin{array}{ll}\text { Urban } & \text { Rural } \\ \text { Coefficient } & \text { Coefficient }\end{array}$

(reference group: illiterate or semi-illiterate)

Primary school

$1.195 * *$

Junior high school

$2.099 * * *$

$1.489 * * *$

$(.152)$

High school or above

Wife's birth cohort

(reference group: 1943-1959)

1960 to 1969

$.654 * * *$

.945

$(.090)$

1970 to 1979

$.674 * * *$

$1.234^{* *}$

1980 to 1992

Pre-marriage family financial situation of husband and wife (reference group: similar)

Woman better

.969

1.114

$(.078)$ (.074)

Man better

Whether or not working in profitable employment

$1.357 * * *$ $(.069)$

$1.186^{* *}$ $(.076)$

Intercept 1.648 ** $(.154)$

$0.812^{* *}$ (.102)

Sample size 5.969 5.490

Cox \& Snell $\mathrm{R}^{2}$

Note $:{ }^{* *} \mathrm{p}<0.01,{ }^{* *} \mathrm{p}<0.05,{ }^{*} \mathrm{p}<0.1$. Standard errors are shown in brackets. 
married couples being equal is steadily increasing. When measured by "joint decision-making", rural areas are catching up with urban areas in terms of "equality between husband and wife".

\section{c. Dynamic changes in domestic decision- making power in the past twenty years}

In general, the percentage of husbands making decisions alone is decreasing, showing a downward trend in "husband's authority". Domestic decision-making patterns are gradually moving towards equality between husbands and wives. Although the percentage of husbands making their own decisions is still higher than that of wives, the difference is becoming smaller, and the percentage of husbands and wives making decisions together is gradually increasing. However, to put this into different contexts, in family matters concerning business, housing, investments or loans, the percentage of husbands making decisions alone is distinctly higher than that of wives. This shows that husbands are relatively more responsible for the family's economic affairs and matters of property. Conversely, a pattern of "wife's authority" is becoming more obvious when it comes to making decisions on daily expenses in the past twenty years. Men's greater decision-making power in relation to family decisions, housing and children's education shows the significance of their power in the family, while women's greater decision-making power with regard to daily expenses shows the ordinariness and triviality of their power in the family (Wang 2009). In matters concerning children's education and career choices, more than two-thirds of married couples make their decisions together. This shows that decision-making in relation to children's education is moving towards a pattern of "equality between husband and wife".

\section{d. Logistic regression analysis of whether married women have domestic decision- making power}

After analyzing trends in women's domestic decision-making power and comparing rural-urban differences in the past twenty years, we shall now use the data from the third Survey on Chinese Women's Social Status in 2010 to conduct a multivariate analysis to see how factors such as women's educational levels, birth cohorts and marriage cohorts affect their domestic decisionmaking power in both urban and rural areas.

Model 1 in Table 4 is the multivariate analysis of whether women have domestic decision-making power. It shows that, in both rural and urban areas, the higher the education level of women, the higher the possibility of making domestic decisions. Women with higher education not only have a better disposition overall, they also have a stronger awareness of gender equality and gender power, and are more active in making domestic decisions. In both rural and urban areas as well, women in gainful employment can significantly increase their ability to make domestic decisions: economically independent women who do not fully rely on their husbands have more say in the family and a better basis for participating more in domestic decision-making. The premarriage economic situations of both the husband's and the wife's family also have a significant impact on married women's domestic decision-making power. If the husband's pre-marriage family's financial situation is better, the wife's likelihood of having domestic decision-making power is less. It may be assumed that, if the husband's family has a better pre-marriage financial situation, then he would contribute relatively more money to the wedding and housing expenses; as a result, he is able to enjoy more decision-making power than his wife. This represents the resource theory mentioned before: one's 
Table 5. Daily domestic labor time of both sexes for both rural and urban areas from 1990 to 2010 (unit: minute)

$\begin{array}{rrrrr} & \text { Women } & & \text { Men } \\ & \text { Urban } & \text { Rural } & \text { Urban } & \text { Rural } \\ 1990 & 269.73 & 321.42 & 134.78 & 132.23 \\ 2000 & 222.44 & 273.98 & 88.39 & 93.71 \\ 2010 & 171.31 & 190.20 & 70.63 & 64.09\end{array}$

power in the family is correlated with the quantity of resources one possesses. The one with the most resources has the greater potential to influence other family members' behavior and thus that person has greater power in the family.

\section{Trends in women's domestic labor time and factors affecting it in the past twenty years}

Domestic labor time is an essential factor in studying the distribution of power of married couples in the family, as it directly affects women's perceptions of their own family status. In addition, the participation of different gender groups in domestic labor is a critical indicator of the progress of gender equality, as this can reflect a woman's family status (Zhou 2013). Since domestic labor may have the characteristics of repetition, a longer time spent in such labor means a greater sacrifice of the time women can spend on their hobbies, entertainment and career development, thus affecting their experience of happiness and perceptions of family status. As mentioned above, traditional gender roles have changed along with China's progress with modernization; in such a context, what is the domestic division of labor between the sexes like in present-day China? Is it more equal now or not? Based on the data from the three phases of the Survey on Chinese Women's Social Status, in the following we will provide an overview of especially the trends in women's time spent in domestic labor in the past twenty years. Using multiple regression methods, we will also determine how factors such as level of education, number of children and income affect married women's domestic labor time, paying particular attention to ruralurban and gender difference.

\section{a. Trends in women's domestic labor time in} the past twenty years

Since domestic labor time can, to a certain extent, reflect relations of power and status between husbands and wives, in the analysis we chose the interviewees whose marital statuses are defined as "married" as our research subject. While investigating women's domestic labor time, we also took men's domestic labor time as a reference point in order to identify trends in the domestic labor time of both genders. Table 5 shows the average daily domestic labor hours of both genders in both rural and urban areas.

From Table 5 it is clear that, regardless of rural or urban origin, both husbands' and wives' domestic labor time has gradually decreased in the past twenty years; compared to 1990, in 2010 husbands halved their domestic labor time, but for wives domestic labor time was only reduced by approximately one third at that date. With the improvements in technology and the popularity of household appliances, people no longer have to spend a lot of 
Table 6. Model 2. OLS analysis of married women's daily domestic labor time

Education level (reference group:

Urban

Coefficient Standardized coefficient
Rural

Coefficient Standardized coefficient

illiterate or semi-illiterate)

Primary school

Junior high school

$\begin{array}{cc}-4.519 & -.028 \\ (8.240) & \\ -10.959 & -.017 \\ (7.747) & \\ -12.458 & -.050 \\ (7.798) & \end{array}$

$-3.016$

$(4.196)$

$-2.802 \quad .012$

(4.467)

$-13.225^{* *}-.034$

High school or above

-12.458
$(7.798)$

(5.977)

Birth cohort

(reference group: 1943-1959)

1960-1969

1970-1979

1980-1992

$\begin{array}{ll}-9.864 * * & .037 \\ (4.128) & \\ -10.791^{* * *} & .044 \\ (4.256) & \\ -11.824 * * & .028 \\ (5.455) & \end{array}$

.877

(4.046)

$-2.738$

(4.393)

$-1.272$

(5.546)
.003

$-.010$

.004

Pre-marriage family financial situation on husband and wife (reference group: similar)

Woman better

\subsection{1}

(3.475)

Man better

Whether or not working in a profitable employment (reference group: no)

Who has more economic contribution to the family? (reference group: similar)

Wife contributes more

Husband contributes more

Number of children

\section{Profitable employment} working hours

Intercept

Sample size

Adjusted R ${ }^{2}$

$$
.922
$$

$-46.674^{* * *}-.185$ (4.398)

$\begin{array}{ll}-.820 & -.003 \\ (3.800) & \\ -2.720 & -.009 \\ (4.014) & \\ -23.858 * * * & -.076 \\ (4.235) & \end{array}$

4.675

(7.260)

6.771 * $\quad .026$

(3.470)

$5.515 * * * \quad .047$

(1.678)

$-.209 * * * \quad-.389$

$(.007)$

190.20

5.490

0.438

Note : ${ }^{* *} \mathrm{p}<0.01,{ }^{*} \mathrm{p}<0.05,{ }^{*} \mathrm{p}<0.1$. Standard errors are shown in brackets. The data from the above table are calculated from the findings of the survey in 2010 . 
time in traditional domestic labor. Also, changes in economic structure have mobilized the rural population to move away for work in non-agricultural jobs, and as a result the time spent on domestic labor has decreased. The table shows that women are still the "main work force" when it comes to domestic labor in China, but we can also see that the differences in domestic labor time between the two sexes in both rural and urban areas has become less in the past two decades. Men and women are becoming more equal in terms of the domestic division of labor. Moreover, widespread local education in rural areas has led to a rise in gender awareness and the female employment rate. These have all contributed to a lower difference in domestic labor time between rural and urban women from almost an hour in 1990 to only $1 / 3$ hour in 2010. However, the difference in domestic labor time between men and women in rural areas is still larger than that in urban areas. Urban areas have a better domestic gender division of labor than rural areas.

\section{b. OLS regression model of factors affecting women's domestic labor timet}

From the trend analysis of married couples' domestic labor time in the past twenty years, it becomes clear that, although the domestic division of labor is becoming more equal, women are still mostly responsible for domestic labor. In the following, we will integrate the factors affecting women's domestic labor time, such as individual educational levels, age, and the relative resources possessed by husband and wife to make an OLS regression model.

We have analyzed the general situation and the trend in domestic labor time of both sexes in both rural and urban areas and have concluded that, although women are still the main force in domestic labor, the differences in the time spent in domestic laboring between men and women are becoming smaller. In the following, we will investigate the factors affecting women's domestic labor time by using the time (minutes) respondents spent daily in domestic labor (data taken from the 2010 survey) as a dependent variable in order to conduct an OLS multiple regression.

With regard to educational level, in both rural and urban areas we find that the higher the educational level of women, the shorter their time spent in domestic labor. However, in rural areas, only women who have been to high school or have higher education have a significantly shorter domestic labor time than other women.

With regard to birth cohort, in urban areas younger women have shorter domestic labor times. This can be understood as the younger generation has a stronger sense of gender equality, and an equal distribution of domestic labor is a characteristic of the post-1980s married group. Besides, younger married women have more work pressures than older women. Older women, due to more flexible working hours, can spend more time in domestic labor. Nonetheless, birth cohort is not a significant factor in affecting women's domestic labor time in rural areas. This may be because women in rural areas are more influenced by traditional gender roles and believe - or have no other options - that women are supposed to be responsible for domestic labor. Therefore the pattern of an equal distribution of domestic labor between men and women is not found in rural areas.

With regard to family economic contributions, when a husband contributes more than his wife, the wife's domestic labor time will be significantly higher than that of women from families where husband and wife have made similar economic contributions. Economic contributions ensure the satisfaction of family members' basic needs, such as food, housing, clothing, transportation and education. In families where the husband contributes more, the 
wife may take up more housework in order to 'repay' him for his contribution. This corresponds to relative-resource theory: the spouse who has more resources can more or less avoid domestic labor. Since the husband has provided his income to the family, the wife, being "disadvantaged" as she has made a lower monetary contribution, will have to take up more domestic labor as a result.

Whether or not women have gainful employment or labor with an income has a significant impact on their domestic labor time. In both urban and rural areas, the analysis shows that women who have an income enjoy 46 minutes and 23 minutes less domestic labor time respectively when compared to women who lack an income. The absolute value of the standardized coefficient in regression equation shows the relative impact of each independent variable. The standardized coefficient of "whether women have a profitable job/ labor" is 0.185 , which suggests that this is the major predictive variable of married women's domestic labor time. Furthermore, an increase in women's working hours leads to a decrease in their domestic labor time. There is therefore a "substitution" effect between work and housework. The standardized regression coefficient of this variable is the highest, which shows that women's working hours are the most important predictive variable for their domestic labor time. In addition, the number of children is significantly and positively correlated with women's domestic labor time in both rural and urban areas. The standardized regression coefficients of this variable are 0.071 and 0.047 respectively. This shows that the number of children is also an important factor in affecting women's domestic labor time in both rural and urban areas. Women in both areas are still more responsible for taking care of the children. The three independent variables that we have just analyzed have relatively bigger standardized regression coefficients. They have at the same time proved the time-availability theory: due to limited time and energy, and whether or not they are employed, the time women spend in the labor market, their type of work and their caring for their own children all significantly affect their reasonable allocation of time. Paid labor thus 'eats' the time for domestic labor.

\section{Logistic analysis of married women's self-evaluated levels of satisfaction with their family status}

We have investigated the general situation of the trends and factors affecting married women's domestic decision-making power and domestic labor time in the past twenty years. Apart from the domestic division of labor and the relative authority of husbands and wives, factors such as the household interactions of husbands and wives and the economic conditions of both also affect women's levels of satisfaction with their family status. In comparison to model 1 , we added five variables in Table 7 , namely "who has more power at home", "who does more housework", "who contributes more economically", "interaction between husband and wife" and "whether or not the woman has control over her own property", in order to investigate which factor has the most significant impact on women's self-evaluated levels of satisfaction with their family status. 5

Among the individual factors, level of education only significantly affects rural women's levels of satisfaction with their family status; the higher educational level a rural woman has, the higher possibility of a better satisfaction level. Educational level determines women's income and ability to handle housework, affecting the distribution of power between husband and wife, and with it the level of women's self-evaluated levels of satisfaction with their family status. From the descriptive statistical analysis above, the fact that there are fewer better educated women in rural areas has 
Table 7. Model 3. Logistic regression analysis of factors affecting married women's self-evaluated levels of satisfaction with their family status. Coefficients are in odds ratio.

Wife's education level

$\begin{array}{ll}\text { Urban } & \text { Rural } \\ \text { Coefficient } & \text { Coefficient }\end{array}$

(reference group: illiterate or semi-illiterate)

Primary school

.954

(.239)

Junior high school

High school or above

1.253

$(.227)$

1.431

$(.228)$

Wife's birth cohort

(reference group: 1943 to 1959)

1960 to 1969

.843

$(.137)$

$.778 *$

$(.139)$

1980 to 1992

Pre-marriage family financial situation of

$.582 * * *$

$(.169)$

husband and wife (reference group: similar)

Woman was better

1.077

$(.116)$

1.043

$(.119)$

1.098

$(.105)$

employment(reference group: no)

Who has more power at home

(reference group: similar)

Wife has more power

Husband has more power

Who takes up more housework

(Reference group: similar)

Wife takes more

Husband takes more

1.277

$(.229)$

Who has more economic contribution to

the family? (reference group: similar)

Wife contributes more

Husband contributes more

1.156

$(.112)$

Individual property control

(reference group: cannot or basically cannot)

Intercept

$3.264^{* * *}$

$(.154)$

.481 * *

$(.299)$

5.969

.072

Cox \& Snell $\mathrm{R}^{2}$
$1.291 * *$

$(.112)$

$1.431 * * *$

$(.121)$

1.529 * *

(.171)

1.178

(.111)

.945

$(.116)$

.961

$(.145)$

1.037

(.108)

1.049

(.113)

1.244*

(.108)

1.218

(.146)

$.635^{*}$

$(.095)$

.815

$(.135)$

.889

$(.195)$

1.004

(.206)

1.392 ** *

(.107)

$3.168^{* * *}$

$(.115)$

$.511^{* * *}$

(.222)

5.490

.066

Note : ${ }^{* *} \mathrm{p}<0.01,{ }^{* *} \mathrm{p}<0.05,{ }^{*} \mathrm{p}<0.1$. Standard errors are shown in brackets. 
made the factor of education more significant in affecting women's levels of satisfaction with their family status. Regarding individual property rights in both rural and urban areas, women with control over their own property are on average three times more likely to have a higher level of satisfaction with their family status than those who do not have control over their own property. This suggests that "economically independent" women are more likely to have a higher level of satisfaction with their family status. In rural areas, if women are engaged in gainful employment or labor, they are $24 \%$ more likely to have a better level of satisfaction with their family status than those who do not have a job. This variable, however, is not significant for urban women.

Married women's birth cohorts do not form a significant variable in rural areas. Yet, in urban areas, women born later are less likely to be satisfied with their family status; the post-1980s group has a significantly lower level of satisfaction with their family status than other groups. This is partly because the post-1980s group had most probably just entered the workplace when they were being interviewed. They are more burdened with economic and career pressures in the face of fierce competition and increasing living costs, which negatively affected their levels of satisfaction with their family status.

Regarding relative authority and economic contributions in the family, women in both rural and urban areas are less likely to be satisfied with their family status when their husbands have more authority, which not only suggests that the distribution of power within the family has a significant impact on women's self-evaluated levels of satisfaction with their family status, it also provides evidence to support the assumptions of resource theory mentioned earlier. Nonetheless, in rural areas, if the husband's economic contribution is relatively greater, the wife is more likely to be satisfied with her family status. This may be due to the fact that rural people tend to be more affected by traditional concepts and that women in rural areas tend to think that men are supposed to be the breadwinners out of a sense of responsibility to their families. Therefore, when a rural man contributes more to the family, his wife may be more satisfied with her family status.

Regarding interaction between husband and wife, women from families with better interaction with their husbands are four times more likely to be satisfied with their family status in both rural and urban areas. This suggests that, apart from 'explicit' factors such as income and economic contribution, 'implicit' factors are also important in affecting women's levels of satisfaction with their family status.

\section{CONCLUSION}

As society progresses, men and women are becoming more equal in terms of education, career opportunities and rewards for labor. More women are educated today, and they are gradually coming out of the house and participating in productive and professional wage work. Economic independence allows women to rid themselves of their traditional roles as domestic laborers, thus changing their family status and their relations with men. At the household level, women's domestic decision-making power and domestic labor time are also important factors in assessing gender equality. These factors reflect the relative authority of men and women in the family, and with it women's self-evaluated levels of satisfaction with their family status.

This article has made use of data from the Survey on Chinese Women's Social Status in 1990, 2000 and 2010 to investigate the general situation and trends in husband and wife's decision-making power in family matters from 1990 to 2010. In China shared decision-making within the family seems to be the preferred pattern. 
Although the percentage of husbands making decisions alone is always higher than that of women, the trend seems to be declining, and the percentage of women who participate in making decisions is increasing. Furthermore, when examined in the context of the rural-urban divide, although rural husbands tend more often to make decisions alone compared to urban husbands, this trend is also declining.

Next, we analyzed the factors affecting women's family power and domestic labor, and rural-urban differences in these regards. We found that, for both areas, women with higher educational levels are more likely to have power. Higher education can give women employment with greater earnings, thus improving their bargaining power in respect of family issues. This is consistent with the findings of an analysis using HRS data which states that decision-making power depends significantly on relative household earnings in the United States (Friedberg and Webb 2006). Birth cohort is a major factor for urban women. Women who are born earlier are more likely to have authority at home, though this is not significant in rural areas. For both areas, the better the man's pre-marriage family financial situation, the less likely it is for his wife to have authority in family. For both areas, women in gainful employment are more likely to have power or influence at home, proving the relative-resource theory. For domestic labor time, we used findings from the three surveys to analyze the general situation and trends in married women's domestic labor time over the past twenty years, We found that, in both rural and urban areas, the extent of both men's and women's domestic labor has shown a slowly declining trend in these twenty years. Rural women work longer hours doing domestic labor than urban women, but the gender division of labor for domestic work is becoming more 'equal'.

We then conducted a multivariate regression analysis of the factors affecting women's domestic labor time. Here we saw that having a paid job and the time spent doing the paid job are important factors affecting women's domestic labor time. Since women have limited time, they have to make a trade-off between work and housework, which also proves the assumptions of the time-availability perspective. A married woman's level of satisfaction with her family status reflects her subjective judgment after considering factors such as her own contribution to the family, the family resources she can control, her power in family etc. Although a higher educational level may lead to greater ability and income for women, educational levels only have a significant impact on rural women. One possible explanation for this difference lies in the "relative scarcity" of educational resources in rural areas. From the descriptive results shown above, in urban areas more than 85 percent of urban respondents have education to junior high school or above, whereas in rural areas, more than 50 percent of respondents are below the level of primary school. Since higher levels of education are more popular in urban areas, this does not have significant impact except in rural areas. In both rural and urban areas, women with control over their own property are more likely to be satisfied with their family status. Also, apart from explicit resources such as income and property in a family, implicit resources are also important. Since the family has an emotional function, women who communicate more and have better interactions with their husbands are more likely to satisfy their own emotional needs and are therefore more likely to be satisfied with their family status. This is an important perspective that cannot be ignored in future research into women's family status. 


\section{Notes}

1. The "Survey on the Status of Chinese women", which was jointly conducted by the China Women's Federation and the National Bureau of Statistics was initiated in 1990 and is taken every ten years. These surveys cover the following aspects related to women: legal status, economy, education, politics, health, marriage and family, lifestyle, gender ideology and gender attitudes. 2. According to the filter criteria mentioned earlier, we included 19637 respondents from the 1990 survey, 16626 respondents from the 2000 survey, and 21958 respondents from the 2010 survey respectively in our analysis here.

3 . As to the birth cohort of the respondents in our analysis, we divide it into four categories: respondents born between 1943-1959, 1960-1969, 1970-1979, and 1980-1992.

4. In this part, the dependent variable we analyzed is the amount of domestic labor time the respondent used the day before the day of the interview. As it is a continuous variable, an OLS regression model is used in the following analysis. In addition, the standardized coefficients are also provided here, making it possible to compare the relative effect of the independent variables.

5 . For the measurement of women's control over individual property, we chose the question "Can you buy expensive goods for your own use?" We collapse the categories "totally can" and "basically can", and assign their value as 1 , which means women have control over individual property; "basically cannot" and "totally cannot" were also collapsed, and were assigned as 0 , which means women do not have individual property control. Based on the synthesis of the above variables and variables in Model 1, we make Model 3. Regression result is showed in Table 7 .

\section{LITERATURE}

- Becker, Gary S. (1985): Human Capital, Effort, and the Sexual Division of Labor, in Journal of Labor Economics No.3, 1985: 833-858.

- Bianchi, Suzanne M., Melissa A. Milkie, Liana C. Sayer, and John P. Robinson. (2000): Is anyone doing the housework? Trends in the gender division of household labor, in Social Forces Vol. 79, No. 1, 2000: 191-228.

- Blood, Robert O. and Donald M. Wolfe. (1960) Husbands and Wives: The Dynamics of Married Living. Free Press, New York.

- Brines, Julie. (1994): Economic Dependency,
Gender, and the Division of Labor at Home, in American Journal of Sociology Vol. 100, No. 3, 1994: 652-688.

. Cao, Lingyan and Yang, Xiaotong (2014): Comparison of Urban and Rural Women's Family Status under the Background of New Urbanization: Based on the Survey of Women's Social Status in Lanzhou, in Northwest Population No. 1, 2014: 86-91

. Chen, Feng (2011): Dependent-control : A Framework for the Current Change of the Women's Status in the Family - Based on the Field Study of a Village Called XingFu in the East of Liaoning Province, in Northwest Population No. 1, 2011: 83-87

- Friedberg, Leonora and Webb, Anthony. (2006). Determinants and consequences of bargaining power in households. NBER Working Paper No. 12367.

. Gong, Jihong and Zhong, zhangbao (2009): An Analysis of the Impact of Education Background on Rural Women's Family Rights and Family Status Satisfaction - Based on Survey of a Village in the City of Jingmen, in Zhejiang Academic No. 2, 2009: 181-186

- Guo, Sufang, Zhao Fengmin, and Wu Jiuling, et al. (2007): Investigation on Gender Conception and Family Status of the Married Women in Rural Area of China, in Maternal and Child Health Care of China No. 29, 2007: 4139-4141

- Li, Chaohai (2013): Relations between domestic labour time, domestic decision-making power and women social status, in Journal of Chongqing University of Posts and Telecommunication (Social Science Edition) No. 4, 2013: 129-135

- Li, Congxin \& Zhang, Zaisheng (2014): Empirical study on urban women's satisfaction level of their family status, in Jianghan Academic No.4, 2014: 5-10

. Liu, Fang \& Zhao, Suisheng (2011): The economic source of men and women social status and its changes, in Journal of Chongqing University of Posts and Telecommunication (Social Science Edition) No. 1, 2011: 91-96

- Liu, Qiming (1994): Theoretical framework and indicators of studies on Chinese women family status, in Chinese Journal of Population Science No. 6, 1994: 1-9

- Liu, Xincai and Li, Yan (2013): The impact of social mobility on rural married women's family status - an analysis based on the findings on Shaanxi Province from the third Survey on Chinese Women's social status, in Collection of Women's Studies No. 5, 2013: 34-42

- Noonan, Mary. (2001): The Impact of Domestic 
Work on Men's and Women's Wages, in Journal of Marriage and the Family Vol. 63, No. 4, 2001: 1134-1145.

- Shan, Yibin (2001): A brief analysis on present evaluation methods of women's family status, in Research on Financial and Economic Issues No. 8, 2001: 74-79

- Song, Shaopeng (2012): From significance to disappearance - domestic labouring in collectivism (1949-1966). In Jiangsu Social Science No. 1, 2012: 98-103

. Wang, Jinling (2009): Gender pattern of family power: inequality or multi-dimensioned distribution? In Journal of Huazhong University of Science and Technology (Social Science Edition). No. 2, 2009: 62-68

-Wang, Qing (2014): Research on women family status - an analysis based on the findings on Hubei Province from the third Survey on Chinese

Women's Social Status. Master's Thesis, in Department of Sociology, Huazhong University.

- Wang, Yiping (2005): Unfinished transition from traditional to modern - a glimpse at women's life style in Shandong, in Collection of Women's Studies No. 2, 2005: 50-55

- Wu, Fan (2014): Women's social and family sta- tus in the relatively given structure of resources: an analysis based on the findings from the third Survey on Chinese Women's Social Status, in Academic Research No. 1, 2014: 2-11

- Xu, Anqi (2005): Evaluation indicators of wifehusband power and women's social status: reviews and reflections, in Sociological Stuides No. 4, 2005: 134-152

- Xu, Anqi and Liu, Wenrong (2003): Domestic labour distribution and its fairness - an empirical study in Shanghai, in Chinese Population Science No.3, 2003: 41-47

- Yang, Juhua (2014): Sustainability and strategy: the gender differences on domestic division of labour in China from 1990-2010, in Academic Research No. 2, 2014: 31-41 - Yu, Jia (2014): Gender conception, modernization and women's domestic labour time, in Society No. 2, 2014: 166-192

- Zhou, Lvjun (2013): Factors affecting urban working couples' participation in domestic labouring - findings from the third Survey on Chinese Women's Social Status, in Collections of Women's Studies No. 9, 2013: 2-11.

- Becker, Gary S. (1981). A Treatise on the Family. Harvard University Press, Cambridge. MA. 